\title{
PEREMPUAN DAN ALAM DALAM WACANA PEMBANGUNAN BERKELANJUTAN (STUDI EKOFEMINISME PROYEK MIFEE) \\ Rahmalia Rifandini ${ }^{*}$ dan Krisnaldo Triguswinri ${ }^{2}$ \\ ${ }^{1}$ Mahasiswa Magister Sosiologi, Universitas Indonesia \\ 2Mahasiswa Magister Administrasi Publik, Universitas Diponegoro \\ *Email: rahmalia.rifandini91@ui.ac.id
}

\begin{abstract}
Abstrak
Cita-cita pembangunan berkelanjutan yang tertuang dalam Tujuan Pembangunan Berkelanjutan (SDGs) menimbulkan persoalan dilematis. Keberpihakan terhadap perlindungan ekosistem hutan dipertanyakan kembali ketika dihadapkan pada kepentingan manusia massal. Sebab, pada kenyataannya, pembangunan berkelanjutan tidak benar-benar mengupayakan keseimbangan alam. Praktik pembangunan berkelanjutan yang diwujudkan oleh MIFEE mengakibatkan marjinalisasi komunitas adat Orang Marind di Papua. Perlakuan alam yang diskriminatif turut mempengaruhi relasi perempuan dan alam. Tulisan ini bertujuan untuk menguraikan 'proyek kekhawatiran bersama' menimbulkan kerentanan produksi di tingkat lokal. Argumen tulisan ini bertujuan menempatkan kepentingan gender dalam analisis untuk menjelaskan keberceraian manusia dan alam dengan bertolak dari relasi perempuan terhadap alam. Penelitian ini dilakukan dengan menggunakan pendekatan kualitatif dengan metode pengumpulan data berupa studi literatur.
\end{abstract}

Kata Kunci: Ekofeminisme, MIFEE, Pembangunan Berkelanjutan

\section{Abstract}

The goals of sustainable development that are contained in the Sustainable Development Goals (SDGs) pose a dilematical issue. The alignments to the protection of forest ecosystems are requestionable when faced with mass human interests. In fact, sustainable development does not really seek the balance of nature. The sustainable development practices created by MIFEE resulted in the marginalization of the Marind indigenous peoples in Papua. Discriminatory natural treatment also affects women and nature relationships. This article aims to describe the mutual concerns project resulting in a production vulnerability at the local level. The argument of this writing aims to place gender interests in analysis to explain the abundance of man and nature by departing from women's relationships with nature. This study was conducted using a qualitative approach with data collection methods through literary studies.

Keywords: Ecofeminism, MIFEE, Sustainable Development

\section{PENDAHULUAN}

Krisis lingkungan semakin kompleks ketika kepentingan penaklukan alam mengendarai proyek pembangunan, juga berakibat terhadap kehidupan kultural masyarakat. Terlebih, pelaksanaan pembangunan diaktualisasikan sebagai pencapaian kebutuhan kehidupan jangka panjang. Proyek MIFEE (Merauke Integrated Food and Energy Estate) merupakan wujud kepengaturan negara untuk memenuhi pasokan pertanian dan perkebunan berskala nasional yang berdampak terhadap pengalihan hutan di Papua. Setidaknya, dibutuhkan lahan sekitar 1.283.000 hektar untuk investasi pertanian [1]. 
Pelaksanaan MIFEE juga menjadi perpanjangan tangan dari agenda Sustainable Development Goals (SDGs) karena berupaya mewujudkan pengentasan kelaparan dan kemiskinan melalui kedaulatan pangan. Tentu ini menjadi dilematis, sebab, pembukaan lahan secara massif bersinggungan dengan capaian target SDGs yang berusaha untuk melakukan perlindungan, restorasi dan pemanfaatan berkelanjutan ekosistem hutan. Terlebih, pendekatan yang digunakan untuk produksi pangan berupa business as usual approach yang akan menyebabkan deforestasi massal. Secara bertahap, implementasi MIFEE tidak hanya merusak keanekaragaman hayati, tetapi juga berdampak pada komunitas di sekitar hutan yang seharihari bergantung pada hutan untuk penyediaan makanan secara langsung. Dengan hilangnya hutan, maka hilang pula layanan ekosistem yang menyediakan pemenuhan kehidupan komunitas tersebut [2]. Salah satu studi Sajogyo Institute terkait pengembangan hutan tanaman industri (HTI) di Sumatera Selatan [3] menunjukkan bahwa perempuan-perempuan yang hidup di sekitar kawasan hutan mengalami perubahan penguasaan sumber daya hutan. Akibat perubahan tersebut, perempuan menjadi teralineasi karena pada masa sebelum masifnya pengembangan HTI, perempuan memperoleh kebutuhan secara langsung dari hutan. Namun, setelah adanya ekspansi ekstraktif hutan, pengalaman perempuan terhadap hutan lebih banyak berkaitan dengan pencemaran hutan.

Meskipun mengedepankan cita-cita pembangunan berkelanjutan untuk pencapaian kedaulatan pangan, namun upaya tersebut hanya sebatas simbolisasi. Sebab, MIFEE pada hakikatnya menghilangkan esensi kultural masyarakat adat Papua yang sangat bergantung terhadap alam. Marind-Anim adalah komunitas etnis terbesar yang tinggal di kawasan mega proyek MIFEE. Bersama kelompok etnis lainnya, seperti Muyu, Mandobo, Mappi, dan Asmat, komunitas-komunitas etnis ini merupakan kelompok yang termarjinalisasi dari realisasi MIFEE. Ini menunjukkan kepentingan pemerintah telah mengabaikan lokalitas setempat berupa basis wilayah kultural [4]. Mengubah lahan hutan sagu menjadi lahan industri pertanian secara luas, tidak hanya mengancam biodiversitas ekosistem hutan tetapi juga entitas budaya komunitas yang tinggal disekitar hutan. Artinya, kepengaturan negara dalam sektor pertanian bertransformasi menjadi proses pengeksklusian yang tampil dalam lingkup budaya dan lingkungan. Kapabilitas komunitas etnis yang bertumpu pada perempuan untuk menjaga keseimbangan alam secara berkelanjutan pun dipinggirkan.

Perkembangan masyarakat bersifat materialistik inilah yang menjadi sentral perdebatan etika ekologi antara antroposentrisme dan ekosentrisme. Masing-masing merupakan antitesis pemikiran yang menumpukan manusia berelasi terhadap alam. Antroposentrisme menempatkan bahwa alam harus menyesuaikan kebutuhan manusia. Sebaliknya, ekosentrisme menekankan keterkaitan antara manusia dan aspek non manusia, yaitu alam dan pengaturan ekologis lainnya, yang melampaui kemampuan pemenuhan material manusia. Kedua isme etika 
lingkungan ini bermuara pada narasi krisis lingkungan yang terjadi saat ini. Namun, simplifikasi persoalan lingkungan tidak terbatas hanya pada isme tersebut. Sebab, yang dibutuhkan ialah rumusan kritis yang mampu berkontribusi sebagai alat politik pembebasan [5].

Munculnya ekofeminisme sebagai pendekatan feminisme ekologi dimulai sejak tahun 1980-an, telah banyak berkontribusi baik untuk perjuangan aktivis maupun untuk memetakan teori hubungan antara penindasan perempuan dan dominasi alam [6]. Namun disisi lain, membangkitkan banyak kekhawatiran karena takut terperangkap dalam penindasan dualistik dengan menyelaraskan kembali perempuan dengan alam, tubuh, dan lingkungan. Namun, sebenarnya ekofeminisme berargumen untuk mendekonstruksi secara kritis atas dominasi historis, budaya, dan sosial terhadap hubungan perempuan dan alam. Pada dasarnya, membawa perempuan kembali ke alam bukan berarti upaya menantang penindasan hierarki dualistik. Melainkan sebuah bentuk perhatian kritis terhadap persimpangan antara penindasan perempuan dan krisis lingkungan. Realisasi dari gagasan ekofeminisme dilakukan dengan meningkatkan kesadaran agar mengoperasikan politik kekuasaan yang melibatkan penderitaan perempuan yang menjadi kelompok terpinggirkan, bawahan, dan lian [7].

Relasi perempuan dan alam dapat dilihat dari perkembangan sistem produksi masyarakat. Apabila mengacu pada perspektif Marxis, perkembangan masyarakat dihasilkan dari sistem kerja dalam memproduksi barang material. Mekanisme mengenai perubahan cara pemenuhan kebutuhan material merupakan hukum dari perkembangan masyarakat itu sendiri [8]. Basis produksi masyarakat primitif bertumpu pada pemenuhan material dari alam secara langsung. Ini terlihat dari pembagian kerja antara laki-laki dan perempuan, di mana laki-laki diposisikan bekerja untuk berburu, sedangkan perempuan bertugas meramu makanan. Relasi pembagian kerja terhadap alam mengkategorikan laki-laki sebagai penguasa alam yang memiliki kuasa untuk merusak alam, dan perempuan dilekatkan pada fungsi merawat alam. Selanjutnya, pada perkembangan masyarakat modern, pembagian kerja yang organik telah menggiring sistem kerja pada ranah keterasingan dari alam. Hal ini menjadi konsekuensi dari perkembangan tenaga produktif melalui hiperindustrialisasi yang bertujuan memperalat alam demi pemuasan manusia.

Sejak 2008 muncul berbagai kekhawatiran akan kerentanan terkait dengan perubahan iklim, gejolak harga, dan kekurangan pangan global. Narasi kebijakan di kawasan global selatan memberikan orientasi kebijakan yang sehubungan dengan kebijakan pangan melalui bingkai 'kedaulatan pangan', 'swasembada pangan' dan 'ketahanan pangan'. Menurut McCarthy dan Krystof [9], narasi ini berfokus pada kedaulatan pangan nasional yang mendukung pertanian berskala besar yang mengabaikan permasalahan yang akan dihadapi oleh komunitas pedesaan terkait persoalan kemiskinan pangan dan marjinalisasi. Agenda kebijakan pangan dengan tema 'swasembada pangan' ini sebenarnya melegitimasi model sistem pangan berbasis industri yang 
didasarkan pada kontrol perusahaan atau perusahaan negara atas tanah dan rantai komoditas pokok tertentu. Masalah utama harus dilihat bahwa pelaksanaan kebijakan pangan merupakan kebutuhan politik negara yang dapat menimbulkan kerentanan produksi lokal. Sebab, ketahanan pangan dipetakan secara kuantitatif, tanpa mempertimbangkan persoalan kultural yang akan muncul.

Dalam konteks pelaksanaan proyek MIFEE yang disahkan oleh negara, titik kritis Orang Marind menjadi dampak yang dihasilkan mega proyek MIFEE. MIFEE merupakan bentuk 'proyek kekhawatiran bersama' terhadap krisis kekurangan produksi yang kemungkinan terjadi di masa yang akan datang. Tujuan artikel ini berupaya mengeksplorasi relasi perempuan dan alam secara kultural. Dengan begitu, pertanyaan penelitian dalam artikel ini yaitu, "Bagaimana posisi perempuan adat Papua terkait dengan opresi terhadap alam dalam konteks pelaksanaan MIFEE?" Pada dasarnya, persoalan lingkungan dapat dipahami berada pada dua poros yaitu instrumental dan spiritual yang mencerminkan pendekatan antroposentrisme dan ekosentrisme [10]. Argumen tulisan ini bertujuan menguraikan keberceraian manusia dan alam dengan bertolak dari relasi perempuan terhadap alam. Studi-studi sebelumnya cenderung masih belum menempatkan kepentingan gender dalam analisisnya. Tulisan ini berangkat dari pendekatan ekofeminisme sebagai pisau analisis.

Ekofeminisme sebagai varian gagasan tentang etika ekologi, juga merupakan suatu pemikiran yang menawarkan gagasan tentang keterhubungan perempuan terhadap alam secara konseptual, simbolik, dan linguistik. Dalam perkembangannya, ekofeminisme memiliki ragam pemikiran yang menitikberatkan pada pertanyaan tentang apakah relasi perempuan dan alam benar-benar berkaitan atau secara kultural perlu adanya pemisahan.

\section{TINJAUAN PUSTAKA}

Aliran pemikiran feminisme Barat seperti feminisme liberal dan feminisme radikal menekankan prinsip kesamaan dan universalitas. Dasarnya terkait dengan persepsi kesamaan karena menolak determinisme perempuan dan laki-laki secara biologis maupun independensi perempuan dari struktur masyarakat yang patriarkis. Menurut Ritzer [10], gerakan feminisme muncul secara politis karena menuntut ke-absen-an perempuan dalam narasi sejarah dan aktivisme masyarakat yang selama ini tidak diperlihatkan Oleh karena itu, penting untuk memahami ranah perjuangan feminisme yang mencakup persoalan aktivisme dan gagasan.

Pada tataran ide, memperjuangkan keadilan perempuan sebagai kelompok minoritas yang tersubordinasi merupakan landasan perjuangan gerakan feminisme. Bagi Ritzer [11], feminisme juga berupaya mewujudkan pencapaian nalar epistemologis dalam paradigma ilmu sosial. Dengan mengajukan bahwa pengetahuan yang berkembang universal lahir dari 
pengalaman laki-laki sebagai kelompok yang berkuasa, sehingga hadirnya feminisme bertujuan untuk meruntuhkan pengetahuan yang bias maskulin.

Gagasan feminisme dapat dilihat secara lebih mendalam melalui gelombang yang menyertai kemunculan gerakan feminisme. Sekitar abad ke-19 hingga abad 21, gelombang pertama gerakan feminisme muncul dengan mengupayakan ide tentang perempuan menjadi bagian dari subjek politik. Konsentrasi isu yang dibahas Butler [12] yaitu mengenai hak memilih bagi perempuan. Momentum gerakan feminisme pertama berakhir ketika disahkannnya Amandemen ke-19 dalam Konstitusi Amerika pada tahun 1919 yang memberikan perempuan hak pilih [13]. Melalui gelombang pertama inilah, lahir sejumlah aliran pemikiran feminisme diantara lain feminis liberal, feminis radikal, dan feminis Marxis dan sosialis [14].

Sentral dari gelombang gerakan kedua yang berlangsung selama tahun 1960 hingga 1970-an yaitu pembebasan perempuan (women liberation). Ini menjadi perlawanan terhadap praktik opresi yang dialami perempuan karena patriarki yang begitu mengakar dalam masyarakat. Salah satunya terkait kritik terhadap beban kerja ganda bagi perempuan yang bekerja di luar maupun di dalam rumah, permintaan upah yang sama antara laki-laki dan perempuan untuk pekerjaan yang sama [15]. Kemudian, gelombang gerakan ketiga hadir untuk merespons serangkaian masa lah teoretis pada gelombang kedua. Gelombang ketiga berusaha meruntuhkan definisi tentang feminitas dan perempuan karena dilatarbelakangi oleh bangkitnya postmodernisme. Feminisme gelombang ketiga menekankan pendekatan inklusif melalui penolakan terhadap narasi-narasi besar tentang feminisme dan menggantikannya dengan feminisme gaya baru (new feminism). Dengan memperhatikan pengalaman dan faktorfaktor kultural seperti ras, etnis, kelas, dan agama, sebagai keragaman kepentingan perempuan [16]. Didalam gelombang ketiga feminisme, terdapat aliran ekofeminisme yang menjadi keterwakilan feminisme yang sarat kontekstual dengan masyarakat negara Dunia Ketiga. Pandangan sinis feminisme terhadap partiarki pada gelombang kedua menunjukkan bahwa perempuan memiliki karakteristik yang sama dan cenderung meng-universalisasi pengalaman perempuan yang beragam [17].

Sebaliknya, feminisme gelombang ketiga menekankan pentingnya individualitas dan pengalaman pribadi untuk mendefinisikan kepentingan politiknya sendiri. Salah satu prinsip inti dari ekofeminisme yaitu secara struktural dominasi perempuan dan dominasi terhadap alam terkait. Mencuatnya gerakan perempuan dan gerakan ekologis yang menentang dominasi yang timbul dari penerapan ekonomi pasar terhadap alam dan masyarakat menjadi bentuk gerakan ekofeminisme yang mengkritik kapitalisme sebagai bentuk opresi ganda. Prinsip kedua ekofeminisme terletak pada pengakuan terhadap nilai-nilai yang secara tradisional selalu dikaitkan dengan perempuan [18]. 


\section{METODE PENELITIAN}

Pendekatan penelitian dalam tulisan ini menggunakan pendekatan kualitatif, dengan teknik pengumpulan data berupa tinjauan literatur. Melalui studi literatur bertemakan ekofeminisme, tulisan ini melakukan studi pustaka terkait posisi perempuan dalam relasinya dengan alam. Tulisan ini menggunakan perspektif ekofeminisme melalui pemikiran Plumwood yang menekankan dualisme manusia dan alam yang menyebabkan keterpisahan perempuan dan alam. Tulisan ini berupaya mengangkat kasus perempuan adat Papua dalam proyek MIFEE. Pada akhir tulisan artikel diharapkan dapat menjadi bahan refleksi dan aktualisasi permasalahan perempuan dan lingkungan.

\section{HASIL DAN PEMBAHASAN}

\section{Pusaran Ekofeminisme tentang Hubungan Perempuan dan Alam}

Perdebatan antara antroposentrisme dan ekosentrisme terkesan dikotomis, menjadi tampak berbeda ketika dipusatkan pada diri perempuan. Ini yang membuat ekofeminisme menjadi menarik. Perempuan dipandang memiliki keterkaitan dengan alam, sebagaimana prinsip dari ekofeminisme yang mengklaim bahwa adanya keterkaitan antara opresi terhadap perempuan dan opresi terhadap alam, sehingga pemahaman tentang eksploitasi terhadap alam dipahami melalui realitas penindasan atas perempuan. Merujuk Putnam Tong [7], ekofeminisme tetap memiliki perbedaan dengan ekologi, yang mana lebih menekankan pada laki-laki sebagai 'musuh' utama perempuan dan alam. Sebab, androsentrisme memusatkan kepengaturan dunia hanya pada laki-laki. Disisi lain, ekofeminisme juga mengkritik ekologi, terutama ekologi-dalam, karena sebagai bagian dari etika ekologi, ekologi-dalam tidak memiliki epistemologis yang memadai untuk menarasikan hubungan konfrontasi antara manusia dan alam.

Ekofeminisme menjadi aliran baru didalam etika ekologi yang tampak seperti mengalternatif-kan perempuan dalam menguraikan masalah ekologi. Perempuan menjadi 'alternatif' terlihat ketika ekofeminisme tidak sepakat memberikan penjelasan tentang hubungan perempuan dan alam, apakah bersifat biologis, psikologis, sosial, ataupun kultural. Terutama perihal pengakuan adanya perempuan berelasi dengan alam, apakah esensinya harus dihilangkan atau justru dipadanankan kembali. Oleh karena itu, didalam ekofeminisme terdapat pusaran argumen yang berupaya menemukan posisi perempuan dalam berelasi dengan alam. Putnam Tong [7] membagi menjadi tiga kelompok, yaitu memisahkan hubungan antara perempuan dan alam, menegaskan kembali hubungan perempuan dan alam, serta argumen yang ketiga, menekankan penghilangan hubungan alam dan perempuan.

Pendapat lain ada yang mengatakan bahwa posisi dalam ekofeminisme terbagi menjadi dua. Pertama, spiritualitas feminis yang mengklaim hubungan dan kemampuan perempuan 
untuk merawat alam. Posisi kedua, menolak hubungan "khusus" perempuan dengan alam dan berupaya melindungi alam melalui upaya mendekonstruksi dualisme alam dan budaya sebagai dikotomi yang salah [19]. Artikel ini berfokus pada literatur yang menguraikan pemisahan perempuan dengan alam.

Pandangan pertama dalam pembagian Putnam Tong [7] yang intinya menolak perempuan memiliki keterkaitan dengan alam berdasarkan nilai-nilai tradisional karena konsekuensi dari pemikiran tersebut mengartikan relasi perempuan dan alam bernilai rendah. Peran-peran perempuan seperti merawat dan mengasuh semata-mata adalah hasil konstruksi kebudayaan yang menempatkan perempuan, tidak seperti laki-laki yang berada pada superioritas, pada status sekunder dalam masyarakat. Laki-laki layaknya kebudayaan lebih superior daripada alam, yang memberikan makna terhadap sistem, termasuk mengatur hubungan manusia dan alam, serta mengontrol dan menguasai alam. Melalui konteks budaya, dapat dipahami secara simbolis atas perempuan yang diidentifikasi dengan alam dan laki-laki diasosiasikan dengan budaya [20].

Kontekstualisasi hubungan perempuan dan alam dilakukan melalui pendekatan budaya. Ortner [21] juga mengarah pada universalitas budaya, bahwa hampir semua budaya melakukan subordinasi terhadap perempuan. Dikatakan bahwa budaya bertanggung jawab untuk mengkonstruksi perempuan dekat dengan alam sebagaimana budaya mengkonstruksi kategori gender perempuan dan laki-laki. Peran perempuan dalam masyarakat lebih dekat kepada alam karena perempuan dilekatkan pada kegiatan-kegiatan reproduksi. Terutama mengasosiasikan perempuan pada domain domestik (rumah tangga). Sama halnya, dengan analisis ruang lingkup perempuan dalam ranah politik yang membatasi perempuan untuk berada di ranah publik.

Ortner [21] mengkategorikan universalitas subordinasi terhadap perempuan yang diperoleh terkait elemen ideologi budaya yang secara eksplisit memberikan peran dan tugas perempuan kurang prestise daripada yang diberikan kepada laki-laki. Lalu, perangkat simbolik, yang diartikan secara implisit membuat penilaian terhadap perempuan lebih rendah, dan pengaturan struktural sosial yang mengecualikan perempuan dari partisipasi masyarakat [21]. Tercermin pada konsepsi mengenai ibu (mother) dan pengibuan (mothering) yang dianggap menjadi suatu pewarisan alami dalam keluarga, serta turut membangun fungsi universal perempuan untuk tetap berada di wilayah domestik. Dengan begitu, menurut Ortner [21] kebudayaan memiliki kepentingan untuk membatasi perempuan atas pendidikan, pekerjaan, dan persoalan seksual.

Ekofeminis lainnya menyikapi keterkaitan perempuan dan alam secara lebih kritis. Keterhubungan antara perempuan dan alam berdasarkan nilai-nilai tradisional memberikan afirmasi terbatas dan berefek pada penegasan kekuatan maskulin yang mengidentifikasi lakilaki sebagai subjek yang dominan, liar, dan kuat, sedangkan perempuan bersifat 'jinak', 
domestik, dan lembut. Plumwood [6] menegaskan bahwa hubungan antara perempuan dan alam yang bersifat inferiorisasi resiprokal tidak berasal dari masa lalu, melainkan terusmenerus terjadi, misalnya, terkait penolakan aktivitas perempuan dari lingkup reproduksi. Penolakan relasi perempuan dan alam, dikatakan Plumwood [6] sebagai 'latar belakang' (backgrounding). Latar belakang atau penolakan perempuan dan alam telah tertanam dalam rasionalitas sistem ekonomi dan struktur masyarakat kontemporer. Apa yang terdapat dalam 'latar belakang' alam adalah penolakan ketergantungan pada biosfer dan pandangan tentang manusia sebagai bagian yang terpisah (di luar alam). Budaya Barat secara dominan dan sistematis merendahkan, 'melatarbelakangi', dan menyangkal ketergantungan pada seluruh bidang reproduksi dan subsistensi. Penolakan ketergantungan ini merupakan faktor utama dalam melanggengkan mode penggunaan alam yang tidak berkelanjutan yang menjadi ancaman bagi masa depan masyarakat. 'Latar belakang' dan instrumentalisasi alam dan perempuan berjalan beriringan. Bagi perempuan, 'latar belakang' dan status instrumental mereka sebagai alam biasanya tidak perlu eksplisit, karena itu membentuk peran dikotomis perempuan di ranah publik dan privat. Perempuan secara 'latar belakang', dapat berperan sebagai ibu rumah tangga, perawat atau sekretaris, dan rekan kerja.

Dalam peran tradisional, kerja perempuan secara sistematis dihilangkan dari perhitungan dalam sistem ekonomi dan tidak diperhitungkan dalam sejarah dan kebudayaan. Secara tradisional, perempuan adalah 'lingkungan'. Dalam hal ini, perempuan yang menyediakan lingkungan dan kondisi yang menjadi tempat 'pencapaian' laki-laki, tetapi apa yang perempuan lakukan tidak dengan sendirinya dianggap sebagai prestasi. Perempuan rentan terhadap penolakan bahkan ketika melangkah keluar dari peran tradisional. Plumwood [6] juga mencontohkan 'latar belakang' yang tampak jelas ketika perempuan berperan sebagai ibu. Keterampilan fisik, pribadi, yang diajarkan kepada sang anak merupakan 'latar belakang' pembelajaran yang didefinisikan sebagai bagian dari ranah akal budi dan pengetahuan pria.

Diri ibu sendiri adalah 'latar belakang' yang didefinisikan terkait dengan anak atau ayahnya seperti halnya alam didefinisikan dalam kaitannya dengan manusia sebagai 'lingkungan'. Realitas identitas manusia di budaya Barat didefinisikan sebagai oposisi dan penyangkalan terhadap alam. Demikian pula produk ibu, menurut Plumwood [6] secara paradigmatik anak laki-laki mendefinisikan identitas maskulinnya dengan menentang keberadaan ibu, terutama terhadap pola pengasuhan ibu, menggantikan dominasi menjadi status instrumental. Sang anak tadi menolak pengakuan akan ketergantungan, namun, secara konseptual mengatur dunia dalam bentuk ruang aktivitas bebas laki-laki (manusia) yang melawan latar belakang kebutuhan perempuan (alami). 


\section{Dualisme sebagai Bentuk Diskontinuitas Perempuan dan Alam}

Merauke ditetapkan menjadi pusat pengembangan pangan. Penetapan ini disahkan melalui proyek Merauke Integrated Food and Energy Estate (MIFEE) dengan mengacu pada Masterplan Percepatan Perluasan Pembangunan Ekonomi (MP3EI) pada tahun 2010. Studi Dewi [1] menunjukkan MIFEE diklaim sebagai proyek pembangunan berkelanjutan karena mengembangkan konsep food estate yang mengintegrasikan produksi pangan yang mencakup pertanian, perkebunan, dan peternakan. Proyek MIFEE dicanangkan untuk meningkatkan ketahanan pangan nasional, sama seperti pendahulunya, yaitu Revolusi Hijau, yang berhasil menciptakan swasembada beras.

Pengambilan langkah strategis pemerintah untuk mewujudkan MIFEE dilatarbelakangi oleh masuknya Indonesia dalam kelompok negara lower middle income country yang memiliki rentang pendapatan per kapita nasional sebesar USD 1.026 hingga USD 4.035 pada waktu itu [22]. Masterplan pembangunan nasional yang menaungi realisasi pusat pengembangan pangan, memberikan MIFEE landasan struktural yang cukup kuat. Beberapa peraturan yang menaungi MIFEE antara lain Undang-Undang Nomor 27 Tahun 2007 tentang Penanaman Modal; Peraturan Pemerintah Nomor 40 Tahun 1996 tentang Hak Guna Usaha (HGU), Hak Guna Bangunan, dan Hak Pakai Atas Tanah; Peraturan Pemerintah Nomor 2 Tahun 2008 tentang Jenis dan Tarif atas Jenis Penerimaan Bukan Pajak dari Penggunaan Kawasan Hutan untuk Kepentingan di Luar Kegiatan Kehutanan, Peraturan Pemerintah Nomor 24 Tahun 2010 tentang Penggunaan Kawasan Hutan, Peraturan Pemerintah Nomor 10 Tahun 2010 tentang Tata Cara Perubahan Peruntukan dan Fungsi Kawasan Hutan; Instruksi Presiden Nomor 5 Tahun 2008 tentang Fokus Program Ekonomi Tahun 2008-2009; Peraturan Pemerintah Nomor 26 Tahun 2008 mengenai RTRWN (Rencana Tata Ruang Wilayah Nasional) yang menjadikan Papua termasuk dalam kawasan sektor pertanian untuk program ekonomi tahun 2008-2009; dan Peraturan Daerah Kabupaten Merauke Nomor 23 Tahun 2010 tentang MIFEE.

Studi Dewi [1] mengemukakan pemilihan Merauke menjadi basis produksi pangan karena dianggap sebagai 'lahan tidur' yang potensial. Didukung juga oleh alasan lain, yaitu pada masa kolonial Belanda, Merauke pernah menghasilkan lumbung padi untuk kawasan Pasifik Selatan. Disamping itu, MIFEE merupakan transformasi proyek pembangunan pertanian milik pemerintah daerah yang tercantum dalam program Merauke Integrated Rice Estate (MIRE) yang terfokus pada penanaman padi sejak tahun 2007.

Konsep pengembangan pangan atau food estate menggunakan pendekatan pembangunan berkelanjutan dalam sektor pertanian berdasarkan pada gagasan Our Common Future yang digagas oleh World Commision on Environment and Development (WCED) pada tahun 1989. Pembangunan berkelanjutan memastikan untuk memenuhi kebutuhan saat ini tanpa mengurangi kemampuan generasi masa depan untuk memenuhi kebutuhan. Konsep 
pembangunan berkelanjutan tidak menyiratkan batasan menerapkan teknologi yang berdampak terhadap sumber daya lingkungan sebagai akibat dari pemenuhan kebutuhan manusia. Akan tetapi, dengan pengelolaan teknologi dan pengorganisasian sosial menjadi era baru bagi pertumbuhan ekonomi yang berkelanjutan. Gagasan Our Common Future ini menganggap bahwa kemiskinan merupakan permasalahan endemik yang akan selalu rentan terhadap bencana ekologis dan lainnya. Dengan begitu, pembangunan berkelanjutan menyediakan pemenuhan kebutuhan dasar dan memperluas kesempatan untuk pencapaian kehidupan yang lebih baik [23].

Dalam konteks pelaksanaan dalam proyek MIFEE, pembangunan berkelanjutan diarahkan untuk percepatan pembangunan yang berorientasi pada masa depan demi mewujudkan ketahanan pangan di Indonesia [24]. Pendekatan pembangunan berkelanjutan dalam MIFEE ditinjau dari sisi pengembangan wilayah, integrasi sektor dan sub-sektor, pendekatan lingkungan berkelanjutan, dan pemberdayaan masyarakat. Dari sisi pengembangan wilayah, food estate menjadi upaya perluasan dan peningkatan produksi pangan yang bertujuan menciptakan sentra produksi pangan serta mendorong perekonomian wilayah [25]. Pengintegrasian sektor dan sub-sektor menekankan sisi keterlibatan pengelolaan dari pemerintah daerah, pemerintah pusat, sektor swasta, dan petani.

Pembangunan ekonomi yang berwawasan lingkungan berkelanjutan dilihat melalui penggunaan sumber daya yang dapat tergantikan dan minim polusi serta dampak lingkungan [26]. Dari sisi pemberdayaan masyarakat, pemerintah bertugas mengarahkan sektor swasta untuk melakukan kerjasama secara terpadu bersama petani lokal. Kerjasama yang berbentuk kemitraan swasta dan masyarakat didasarkan pada kepemilikan natural asset berupa tanah ulayat masyarakat adat. Tujuan pemanfaatan dari bagi hasil swasta dan masyarakat adalah untuk membiayai investasi yang menjadi modal bagi peningkatan kualitas hidup masyarakat lokal [27].

Pendekatan neoliberalisme yang diterapkan dalam mega proyek ini, memperlihatkan keberpihakan negara yang mempersilakan perusahaan-perusahaan untuk menggarap 'lahan tidur' di Merauke [28]. Keberpihakan ini, secara kasarnya, mengusir keberadaan komunitas asli Orang Marind yang sudah ratusan tahun mendiami wilayah tersebut. Fakta peminggiran mirisnya dilakukan negara diatas cita-cita pembangunan berkelanjutan.

Dalam konteks masyarakat Papua secara umum, melalui pembacaan literatur teks-teks, perempuan Papua mempengaruhi keberlangsungan alam [29]. Misalnya, dalam kehidupan Suku Wamesa dan Irarotu di Teluk Bintuni, Papua Barat, pada ekosistem hutan mangrove. Meskipun perempuan menjalankan tugas produktif, reproduktif, dan sosial sekaligus, namun dalam pemenuhan kebutuhan domestik, perempuan memperhatikan pengelolaan hutan mangrove 
secara berkelanjutan. Ketika mencari kayu bakar di hutan, perempuan tidak melakukan penebangan, melainkan hanya memungut ranting-ranting tumbuhan yang sudah kering [30].

Pada lingkup Orang Marind, kekerabatan erat dengan alam, terutama keterikatan dengan tanah terbentuk secara spiritual. Keterikatan ini juga mengikat Orang Marind dengan tanah dalam hubungan sosial. Pembentukan identitas, proses produksi material, termasuk pertukaran sosial dalam komunitas Orang Marind, ditentukan oleh penguasaan tanah. Oleh karena itu, bagi Orang Marind, tanah memiliki nilai yang sangat tinggi. Nilai tanah sangat bergantung, salah satunya, pada perubahan lanskap dan perubahan lokasi kekuasaan internal dan eksternal. Hak atas tanah ditentukan oleh interaksi sosial. Keputusan penggunaan tanah sangat jarang ditentukan oleh individu, melainkan berdasarkan garis keturunan, sejarah penggunaan tanah, sejarah hubungan sosial antar anggota marga, dan mitologi komunitas etnis Orang Marind. Meskipun tanah melekat dalam hubungan sosial Orang Marind, namun tanah tidak bermakna sebagai komoditas [31].

Merujuk pada kosmologi Orang Marind, alam dipandang sebagai seorang ibu yang menjadi sumber kehidupan. Khususnya hutan, yang menyediakan segala kebutuhan pangan, seperti sagu, hewan buruan, dan berbagai jenis tumbuhan. Layaknya seorang ibu bertugas mengasuh, merawat dan memberi kenyamanan, maka hutan adalah rumah di mana sebagian besar komunitas etnis di Kabupaten Merauke tinggal. Termasuk pula Orang Marind yang hidup di hutan secara pindah-pindah. Orang Marind merasa bahwa hutan adalah nenek moyang mereka, tempat di mana Orang Marind berasal [42]. Hal ini terlihat dari setiap marga Orang Marind yang mengasosiasikan dirinya dengan tumbuhan atau hewan di hutan. Misalnya, marga Gebze yang melambangkan dirinya dengan pohon kelapa, identitas marga Samkakai yang melekat pada kangguru, marga Mahuze yang mengobjektifikasi dirinya lewat sagu, marga Kaize yang mengasosiasikan kelompoknya melalui kasuari [32].

Kemelekatan identitas Orang Marind dengan hutan menunjukkan besarnya ketergantungan Orang Marind terhadap alam. Konsekuensi ketika hadirnya MIFEE yang mengalihfungsikan hutan menjadi lahan non hutan pun mengancam hilangnya identitas diri Orang Marind. Masifnya teknologi yang diterapkan dalam investasi pertanian mega proyek MIFEE tidak signifikan bagi penghidupan Orang Marind, sebab, kehidupan Orang Marind yang bersumber dari alam itu dianggap tertinggal. Peningkatan produktivitas produk pertanian merupakan prioritas utama dalam proyek MIFEE. Upaya ini menjadi pembelaan untuk mewujudkan modernisasi pertanian. Disisi lain, kebergantungan terhadap alam sebagai entitas budaya masyarakat seringkali diabaikan oleh pihak yang berkuasa.

Pola perampasan lahan dalam proyek MIFEE berhasil menjadi praktik marginalisasi terhadap Orang Marind di tanah kelahirannya sendiri. Orang Marind menjadi terancam karena harus mengubah jatidirinya, dari kebiasaan makan sagu menjadi makan nasi. Perubahan pola 
makan ini mengartikan 'jawanisasi', di mana pemenuhan kebutuhan dilakukan dengan menggantikan hutan sagu menjadi lahan sawah yang dengan terpaksa harus mendatangkan tenaga kerja petani dari luar yang kebanyakan dari Pulau Jawa. Situasi ini dapat menjadi lebih parah karena kedatangan tenaga kerja yang lebih terampil akan menggantikan komunitas asli Papua. Dengan kata lain, proyek MIFEE menjadikan Orang Marind persis seperti anak yang dipisahkan dari ibu kandungnya.

Perempuan sebagai makhluk yang memiliki hubungan terhadap alam pun akan mulai bergeser dimana peran mereka untuk mengambil sumber makanan di alam akan bergeser untuk bercocok tanam, sehingga hal itu akan memunculkan adanya sikap untuk memperoleh keuntungan dari alam secara finansial dengan adanya proyek tersebut. Padahal sebelumnya masyarakat Papua memperoleh makanan itu tanpa pernah memikirkan tentang keuntungan secara finansial yang harus mereka pikirkan tetapi hanya berfikir bahwa dengan menjaga alam tetap terjaga dan lestari maka kebutuhan akan hidup mereka akan terpenuhi. Maka bisa dikatakan bahwa program tersebut akan menciptakan kerusakan terhadap alam yang ada dan manusia akan memiliki kecenderungan untuk menciptakan kerusakan yang ada. Sudah seharusnya pemerintah memahami apa yang dibutuhkan oleh masyarakat Papua bukan mengarahakan cara hidup orang papua dengan orang-orang yang duduk di kursi pemerintahan yang dimana setiap hari memakan nasi, bukan memakan sagu.

Konsep pembangunan berkelanjutan yang digagas oleh pemerintah saat ini hanyalah bualan semata untuk memenuhi kepentingan kelompok tertentu yang dimana mereka bukanlah masyarakat adat papua, karena nyatanya sebenarnya mereka tidak membutuhkan itu untuk maju. Adanya proyek ini hanya akan memunculkan terjadinya kerusakan saja, sehingga seharusnya pemerintah lebih memahami dan mampu memetakan daerah mana saja yang bisa dicanangkan untuk program ini, bukan untuk semua daerah untuk dipaksa makan nasi, karena hal itu mengingatkan kita akan masa lalu bangsa ini yang sebelum adanya pertanian kita semua masihlah makan sagu. Dengan bergesernya konsumsi pokok masyarakat Papua dari sagu ke beras maka akan menciptakan kerusakan lingkungan yang nyata, karena hutan pada akhirnya akan berkurang dan hilang. Namun, ketika semua proyek itu sudah berada dalam proses, maka hal itu tidaklah bisa dihindari lagi. Masalah muncul karena penguasaan atas lahan yang ada itu sudah seharusnya bukan milik investor ataupun privat. Akan tetapi, lahan seharusnya dikuasai oleh masyarakat asli Papua agar hal itu bisa menciptakan pertumbuhan secara ekonomi maupun sosial masyarakat Papua. Jika hal itu tidak bisa dilaksanakan maka seharusnya negara adalah organ yang menguasai dan mengelola itu untuk digunakan sebesar-besarnya guna kemakmuran masyarakat papua. Bukan hanya untuk mensejahterakan segelintir pengusaha. Karena jika hal itu dikuasai oleh privat maka hal itu tak ubahnya seperti perkebunan sawit yang kebanyakan dikuasai oleh sekelompok pengusaha terutama pengusaha asing. 
Ketika membicarakan tentang pembangunan maka sudah menjadi suatu konsekuensi bagi negara untuk menciptakan adanya kerusakan terhadap sistem tatanan alam yang ada. Sistem tatanan yang dimaksud yaitu antara manusia dengan alam ataupun alam dengan alam itu sendiri. Pembangunan secara fisik, seperti MIFEE yang digalakkan di Papua, diklaim sebagai pembangunan pertanian yang menerapkan konsep pembangunan berkelanjutan. Padahal yang terjadi sebaliknya, sebagai pembangunan pertanian berkelanjutan terdapat kesalahan dalam menafsirkan tentang Papua, bagaimana orang Papua hidup, termasuk bagaimana orang Papua memperoleh makanan secara langsung dari alam.

Dalam kehidupan Suku Wamesa dan Irarotu, perempuan memiliki tanggung jawab yang lebih banyak daripada laki-laki. Disamping memenuhi 'perut keluarga' seperti mencari ikan atau karaka (kepiting) dan menokok sagu yang kemudian dijual ke pasar, perempuan Suku Wamesa dan Irarotu juga harus menjalankan peran sebagai ibu yang bertugas untuk mendidik dan mensosialisasikan anak-anaknya tentang pengelolaan alam. Berbagai peran yang dipraktikkan perempuan Suku Wamesa dan Irarotu seringkali mendapat predikat bahwa perempuan menjalankan beban ganda. Alih-alih perempuan Suku Wamesa dan Irarotu dianggap tersubordinasi karena berada di ranah domestik, namun sebenarnya itu menjadi upaya perempuan Suku Wamesa dan Irarotu dalam menjaga keanekaragaman hutan mangrove. Justru perempuan-lah yang menguasai pengetahuan tentang alam sebagaimana tercermin dalam kegiatan mencari karaka dan menokok sagu. Sagu adalah makanan pokok bagi masyarakat Papua, bukan nasi. Masyarakat Papua memang mengandalkan hutan sebagai sumber makanan bagi keberlangsungan hidup bagi mereka. Mereka yang sehari-hari tinggal berdekatan dengan alam, hanya perlu masuk ke dalam hutan dan menebang pohon sagu untuk diolah menjadi makanan. Di hari itu juga mereka bisa mencukupi kehidupan keluarga selama berbulan-bulan tanpa harus menanam. Untuk memperoleh lauk-pauk, mereka hanya perlu membawa tombak atau panah untuk berburu hewan ataupun ikan di hutan dan kebutuhan hidup mereka sudah terpenuhi.

Kehidupan Suku Wamesa dan Irotu setidaknya cukup menggambarkan kehidupan Orang Marind di Kabupaten Merauke yang menekankan alam sebagai pusat kehidupan. Ketika adanya proyek MIFEE tentu akan mempersulit penghidupan Orang Marind karena hanya akan menjauhkan mereka terhadap alam. Hadirnya proyek MIFEE yang digadang-gadangkan itu, jelas bertentangan dengan konsep hidup orang-orang Papua yang menggantungkan hidupnya terhadap alam. Masyarakat Papua selama ini tidak perlu melakukan usaha pertanian ataupun peternakan, karena alam sudah menyediakan semua kebutuhan. Akibatnya, sikap ketergantungan terhadap alam mulai tersingkirkan, dan lambat laun kepedulian mereka terhadap alam pun akan hilang pula. 
Proyek MIFEE menjadi kekerasan budaya bagi masyarakat Papua, terutama yang dialami oleh perempuan. Bagi sebagian pendapat ekofeminis, fakta tentang kapasitas prokreasi perempuan yang menjadi sumber ikatan biologis yang memberi kehidupan. Menurut Longenecker [19], hubungan dengan alam ditunjukkan sifat metaforis seperti "alam ibu" (mother nature) atau "ibu bumi" (mother earth). Dalam mitologi Suku Wamesa, binatang berjenis kelamin betina yang hidup di hutan merupakan nenek moyang Suku Wamesa. Binatang berjenis kelamin betina ini diyakini melahirkan manusia. Personifikasi binatang yang melahirkan manusia memang menunjukkan sifat feminin yang lekat dengan perempuan. Disisi lain mitos Suku Wamesa juga mengartikan bahwa sebetulnya dari alam-lah manusia lahir. Bahwa sejak dulunya manusia telah hidup dan tinggal berdekatan dengan alam. Simbolisasi alam sebagai ibu menunjukkan sebuah penghormatan bahwa agar manusia dapat menjaga dan melestarikan alam. Kehidupan yang dekat dengan alam menandakan tidak ada hierarki antara manusia dengan alam, atau antara manusia dan hewan. Orang-orang saling peduli satu sama lainnya dan bahkan terhadap non manusia yaitu untuk alam, dimana bumi dan hutan dipertahankan 'misteri', kekuatan dan keutuhannya. Setidaknya ini menjadi sebagian gambaran tentang kehidupan yang dikendalikan oleh karakteristik feminin dari alam.

Pada kenyataannya, manusia sebagai anak dari alam telah berbuat durhaka kepada ibu melalui eksploitasi alam. Melalui kekuatan teknologi dan militer, alam ditundukkan dibawah kekuatan ekonomi global demi pencapaian menguasai bumi. Penguasaan teknologi memadamkan, baik alam maupun budaya yang 'tidak rasional'. Akibatnya, manusia harus menghadapi kenyataan hilangnya hutan bersamaan dengan sebagian besar keanekaragaman spesies dan manusia. keanekaragaman budaya. Padahal, banyak budaya yang memiliki dasar pola bertahan hidup yang selama ratusan tahun [34].

Munculnya spesies pembangunan dan 'kemajuan' merupakan suatu yang tidak dapat dihindarkan. Kehadirannya hadir dengan tujuan untuk menghasilkan kehancuran alam dan ketimpangan yang tak terhindarkan, seperti yang menghasilkan polusi dan limbah. Sebabnya ialah dominasi manusia 'rasional' yang akhirnya mengancam dan menghasilkan hasil yang paling tidak rasional, berupa kepunahan spesies. Menurut pemikiran Plumwood [6], mengatakan bahwa kehidupan dunia yang didominasi oleh 'laki-laki' bukan suatu kebetulan. Apabila membandingkan feminitas dalam menguasai alam, maka dapat perempuan dapat melepaskan diri dari segala bentuk dominasi. Plumwood [6] menggambarkan penguasaan yang feminin itu diibaratkan dengan sebuah planet dengan ekosistem yang sehat dan seimbang. Terutama dalam sistem pengaturan kehidupan yang berkelanjutan. Salah satu yang penting dari pendekatan ekofeminisme, yaitu memberikan nilai positif pada hubungan perempuan dengan alam. Berbeda dari itu, pandangan Barat justru memberikan penilaian yang negatif terhadap 
keterhubungan keduanya, sehingga pandangan ini yang menjadi utama devaluasi dan penindasan perempuan.

Bentuk-bentuk penindasan dari masa lalu sebenarnya masih meninggalkan jejak sebagai jaringan dualisme. Struktur logis dari dualisme membentuk dasar utama hubungan antara bentuk-bentuk penindasan. Konsep dualisme merupakan pemikiran filosofis dan menyediakan landasan terhadap feminis, namun terbatas pada pengartikulasian secara samar-samar. Plumwood [6] mengkaji konsep dualisme dalam ekofeminisme secara lebih lengkap dengan menekankan pada kritik terhadap politik dan budaya. Budaya Barat telah memperlakukan hubungan manusia dan alam sebagai dualisme, yang menjelaskan perlakuan Barat terhadap alam telah mendasari krisis lingkungan. Terutama konstruksi Barat tentang identitas manusia yang didefinisikan sebagai 'diluar' alam. Analisis yang mendetail tentang dualisme, menunjukkan bahwa struktur logis yang memperlihatkan keberbedaan (otherness) dan penegasian.

Konsep nalar (akal) menentukan cara pandang terhadap alam, seperti konsep suami untuk istri sebagai tuan bagi budak. Akal dalam tradisi Barat telah dikonstruksi sebagai wilayah istimewa dari 'master' untuk memahami alam sebagai seorang istri atau bawahan yang meliputi dan mewakili bidang materialitas, subsistensi, dan feminin yang telah dipisah dan dibangun oleh 'sang master'. Menguasai domain alam secara terus-menerus dan kumulatif berangkat dari alasan untuk melahirkan konsep kemajuan dan pembangunan. Pandangan Plumwood [6] tentang master dikaitkan dengan laki-laki dalam budaya patriarki karena identitas maskulin yang melekat pada laki-laki. Identitas master ini yang mengkonstruksi eksploitasi alam, seperti halnya ayah yang mengambil keuntungan dari anak yang dimilikinya serta merendahkan peran ibu dalam pengasuhan.

Penjelasan tentang eksklusi akal dalam perjuangan pembebasan menjelaskan hubungan konseptual antara berbagai kategori dominasi, terutama dominasi manusia dengan dominasi alam. Alam merupakan ranah eksklusi dan kontrol yang berganda. Eksklusi tidak hanya terjadi pada non-manusia, tetapi juga berbagai kelompok manusia dan aspek kehidupan manusia yang berperan sebagai alam. Dalam konteks ini, kolonialisme dan seksisme telah membentuk konseptual tentang perbedaan seksual, ras dan etnis yang mirip dengan hewan dan tubuh. Hal ini ditafsirkan sebagai ruang inferioritas, sebagai bentuk kemanusiaan yang lebih rendah dan tidak memiliki ukuran rasionalitas. Hubungan antara bentuk-bentuk dominasi Barat merupakan hasil evolusi historis tertentu, yang terbentuk dari keharusan logika dominasi antara diri dan other serta akal dan alam. Alam dalam konteks ini didefinisikan sebagai pasif, sebagai non-agen atau non-subjek. Lingkungan didefinisikan kondisi latar belakang yang tidak kelihatan yang dengannya 'latar depan' pencapaian akal. Pemikiran Plumwood [6] bertujuan untuk menganalisis dualisme antara nalar dan alam serta dampaknya pada hubungan manusia. 
Dengan karakteristik lebih lanjut pada lingkup diri dan lainnya (other), ruang publik atau privat, serta dualisme nalar dan emosi.

Plumwood [6] memfokuskan analisisnya pada rasionalisme dan dualisme yang merujuk pada a gendered reason and nature contrast sebagai bentuk sentral dalam pemikiran Barat yang diuraikan dalam struktur dualistik seperti budaya dan alam, pikiran dan tubuh, laki-laki dan perempuan, serta subjek dan objek. Namun, hubungan ini berbeda dari dikotomi, non-identitas, atau perbedaan dengan konstruksi penindasan yang sistematis. Menurut Hawkins [33], pengertian tentang master yang menunjukkan superioritas terhadap other sebagai entitas yang inferorior. Setidaknya terdapat lima karakteristik dualisme, yaitu (1) latar belakang atau penolakan, (2) eksklusi atau hiperseparasi radikal sebagai bentuk diskontinuitas absolut, (3) penggabungan atau definisi relasional, di mana other didefinisikan dalam hal kurangnya kualitas yang dimiliki oleh master, sebaliknya, hanya yang berkualitas dapat dimasukkan ke dalam kebutuhan dan keinginan master; (4) instrumentalisme atau obyektifikasi, di mana other hanya diakui sebagai objek, sumber daya atau sarana untuk tujuan master daripada sebagai subjek yang memiliki tujuan sendiri; dan (5) homogenisasi atau stereotip, di mana semua anggota kelas yang tertindas dipandang seragam dan stereotip, dilucuti dari semua individualitas atau perbedaan. Karakteristik ini yang menjelaskan dualisme, yang diidentifikasi sebagai "garis fraktur" yang paradigmatik dalam seluruh kebudayaan Barat. Bahwa hampir semua hal pada sisi 'superior' direpresentasikan sebagai bentuk-bentuk akal, sedangkan semua yang berada dibawah dapat direpresentasikan sebagai bentuk-bentuk alam.

Pemahaman tentang eksklusi dan dominasi akal budaya Barat tidak hanya mencakup perempuan dan alam, tetapi semua tatanan manusia yang diperlakukan sebagai alam dan tunduk pada ketergantungan. Identitas sang master bukan merupakan identitas maskulin yang murni dan sederhana. Identitas ini diekspresikan dalam konsepsi akal yang dominan dan memunculkan struktur dua sisi yang berbeda. Apabila hubungan kekuasaan budaya Barat yang berlaku telah menentukan pemilihan teori logis, maka untuk menolak struktur pemikiran yang tidak menyiratkan penolakan dari semua upaya untuk alasan struktur.

Dualisme juga dapat dilihat sebagai bentuk diferensiasi yang teralienasi, di mana kekuasaan mengkonstruksikan perbedaan dalam hal ranah inferior. Menurut Plumwood [6] dalam kekuasaan tirani, manusia dipilih untuk melakukan penindasan secara sewenangwenang. Tetapi dalam bentuk kekuasaan yang sistematis, kekuasaan biasanya dilembagakan dan 'dinaturalisasi' dengan mengaitkan pada bentuk-bentuk perbedaan yang ada. Dualisme bukan hanya sistem ide yang mengambang; melainkan terkait erat dengan dominasi dan akumulasi, dan merupakan ekspresi dan pembenaran budaya utama. Lingkungan material dan budaya melakukan pekerjaan dominasi dan dapat dipilih oleh pengaturan sosial dan politik tertentu untuk mempertahankan, memperkuat, suatu struktur sosial tertentu, seperti halnya 
teknologi. Himpunan dualisme yang saling terkait dan saling menguatkan yang menembus budaya Barat membentuk garis patahan yang melintasi seluruh sistem konseptualnya. Sementara, kontras manusia dan alam adalah salah satu bentuk dualisme yang dapat sepenuhnya dipahami hanya sebagai bagian dari himpunan saling terkait. Masing-masing memiliki koneksi penting ke elemen lain, dan memiliki struktur yang sama dengan yang lain. Dualisme merupakan logika kolonisasi yang harus dilihat sebagai pembentukan sistem, struktur yang saling terkait.

\section{KESIMPULAN}

Munculnya ekofeminisme atau feminisme ekologis bertujuan mendekonstruksi secara kritis atas dominasi historis, budaya, dan sosial terhadap perempuan dan alam. Perhatian kritis terhadap penindasan perempuan dan krisis lingkungan meningkatkan kesadaran tentang politik kekuasaan yang melibatkan penderitaan berbagai kelompok yang terpinggirkan sebagai bawahan. Kasus MIFEE mencerminkan perlakuan terhadap alam berdampak terhadap relasi perempuan dan alam. Pola perampasan lahan dalam proyek MIFEE berangkat dari paradigma dualisme yang menekankan diferensiasi antara manusia dan alam. Oleh karena itu, alam harus tunduk dibawah kepentingan manusia. Ini berakibat pada praktik marginalisasi terhadap Orang Marind di tanahnya sendiri. Terutama, perempuan yang semula memiliki otonomi pengetahuan tentang pengelolaan alam dan pemenuhan menjadi terpinggirkan. Pelaksanaan MIFEE yang terwujud dalam intensifikasi lahan pertanian monokultur yang dibingkai wacana 'kedaulatan pangan', pada akhirnya merupakan ditujukan untuk segelintir pihak tertentu.

\section{DAFTAR PUSTAKA}

[1] Dewi, Rosita. 2016. Dilema Percepatan Pembangunan dan Permasalahn Pembangunan Berkelanjutan dalam Pelaksanaan MIFEE di Merauke. (http://ejournal.politik.lipi.go.id/index.php/jpp/article/view/448/261) diakses pada tanggal 11 Desember 2019.

[2] Katila, Pia.et.al. (C) 2020. Sustainable Development Goals: Their Impacts on Forests and People. United Kingdom: Cambridge University Press.

[3] Siscawati, Mia dan Noer Fauzi Rachman. 2015. Gender dan Politik Konsesi Agraria. Working Paper Sajogyo Institute.

[4] https://suarapapua.com/2016/06/18/mifee-dan-ancaman-eksistensial-masyakarat-papua/

[5] Setiawan, Tomi. 2017. Ethnodevelopment: Solusi Atas Kegagalan Kebijakan Pembangunan pada Masyarakat Adat.

[6] Plumwood, Val. 1993. Feminism and the Mastery of Nature. Routledge: London.

[7] Putnam Tong, Rosemarie. 2009. Feminist Thougt. Colorado: Westview Press

[8] Suseno, Franz-Magnis. 1999. Pemikiran Karl Marx : Dari Sosialisme Utopis ke Perselisihan Revisionisme. Jakarta: PT Gramedia

[9] McCarthy, John F dan Krystof Obidzinski. 2017. Framing the Food Poverty Question: Policy Choices and Livelihood Consequences in Indonesia. Journal of Rural Studies, Vol. 56: (344354) 
[10] Thompson, Suzanne, dan Michelle. 1994. Ecocentric and Anthropocentric Attitudes Toward The Environment. Journal of Environmental Pscychology, No. 14 : (149-157)

[11] Ritzer, George. 2003. Teori Sosiologi Modern. Terjemahan, Alimandan. Jakarta: Kencana

[12] Butler, Judith. 1990. Gender Trouble. New York: Routledge

[13] Drucker, Sally Ann. 2018. Betty Friedan: The Three Waves of Feminism. (http://www.ohiohumanities.org/betty-friedan-the-three-waves-of-feminism/) diakses pada tanggal 14 Desember 2019.

[14] Susilawati. 2017. Feminisme Kelombang (https://www.jurnalperempuan.org/wacana-feminis/feminisme-gelombang-ketiga) diakses pada tanggal 14 Desember 2019.

[15] Kroløkke, Charlotte dan Anne S. Sørensen. 2005. Gender Communication Theories \& Analyses: From Silence to Performance

[16] Snyder, R. Claire. 2008. What Is Third-Wave Feminism? A New Directions Essay. Signs, Vol. 34, No. 1: (175-196). The University of Chicago Press

[17] Mahoney, Kate. 2016. Historicising the Third Wave: Narratives of Contemporary Feminism. Women's History Review. (DOI: 10.1080/09612025.2015.1131052)

[18] Thompson, Charis. 2006. Back to Nature? Resurrecting Ecofeminisme After Poststructuralist and Third- Wave Feminisims. Isis, Vol. 97. No. 33: (505-512)

[19] Longenecker, Marlene. 1997. Women, Ecology, and the Environment: An Introduction. NWSA Journal, Vol. 9, No. 3: (1-17)

[20] Moore, Niamh. 2004. Ecofeminism as Third Wave Feminism? Essentialism, Activism, and the Academy

[21] Ortner, Sherry. 1996. Making Gender: The Politics and Erotics of Culture.

[22] Saputra, Wiko. 2014. Pembangunan Ekonomi dan Terancamnya Hak Dasar Masyarakat: Kritik dan Kajian terhadap Kebijakan MP3EI 2011-2025. Jakarta: Perkumpulan Prakarsa.

[23] https://sustainabledevelopment.un.org/content/documents/5987our-common-future

[24] https://ekonomi.bisnis.com/read/20120415/99/72620/food-estate-konsep-kawasanpangan-skala-luas-akan-tetap-dilanjutkan

[25] Rumusan Seminar Nasional "Food Estate di Indonesia". 2010. Bogor.

[26] Jaya, Askar. 2004. Konsep Pembangunan Berkelanjutan. Bogor: Institut Pertanian Bogor.

[27] http://old.litbang.pertanian.go.id/berita/one/819/file/Bagian-1.

[28] Zakaria, R.Yando, Emilianus Ola Kleden, Y.L. Franky. 2011. MIFEE: Tak Terjangkau Angan Malind. Jakarta: Yayasan PUSAKA

[29] Hardiningtyas, Puji Retno. 2016. Resistansi Perempuan Papua di Lingkungannya dalam Roman Isinga Karya Dorothea Rosa Herliany.

[30] P.M. Laksono, et.al. 2000. Perempuan di Hutan Mangrove: Kearifan Ekologis Masyarakat Papua. Yogyakarta: Pusat Studi Asia Pasifik Universitas Gajah Mada.

[31] Darmanto, 2014. Biografi Tipis Tanah Marind Anim. Wacana Jurnal Transformasi Sosial, Vol. 16, No. 33: (235-245)

[32] Barahamin, Andre. 2015. Hikayat Beras Pemangsa Sagu: Etnosida terhadap Malind-Anim melalui Mega Proyek MIFEE. (https://indoprogress.com/2015/10/hikayat-beraspemangsa-sagu-etnosida-terhadap-malind-anim-melalui-mega-proyek-mifee/) diakses pada tanggal 15 Desember 2019

[33] Hawkins, Ronnie Zoe. 1998. Ecofeminism and Nonhumans: Continuity, Difference, Dualism, and Domination. Hypatia, Vol. 13, No. 1.

[34] Moore, Henrietta. 1998. Feminisme dan Antropologi. Terjemahan Tim Proyek Studi Jender dan Pembangunan FISIP UI. 